\title{
THE QUALITY OF ACCOUNTING INFORMATION: RELEVANCE OR VALUE-RELEVANCE?
}

\author{
Nasrin Azar*, Zarina Zakaria and Noor Adwa Sulaiman
}

\begin{abstract}
Research aim: This paper critically evaluates the qualitative characteristics of accounting information that can be drawn from the Financial Accounting Standard Board (FASB)/International Accounting Standard Board (IASB) Conceptual Framework and Value-Relevance studies that are motivated by users of accounting information.
\end{abstract}

Design/Methodology/Approach: This study reviews the value-relevance literature and Statement of Financial Accounting Concepts (SFAC) No. 8, which was issued by FASB in September 2010 in order to make a distinction between them.

Research findings: The value-relevance literature, which reported the associations between accounting numbers and common equity valuations, has limited implications or inferences for accounting information users. Although some scholars believe that the value relevance model indicates that accounting information is relevant and reliable (faithfully represented), it is, however, difficult to attribute the cause of the lack of value relevance to the relevance or the reliability aspects as the value relevance model does not distinguish between relevance and reliability.

Theoretical contribution/Originality: This study provides some recommendations and a framework for future academic research related to the qualitative characteristics of accounting information (especially earnings) and value-relevance models.

Practitioner/Policy implications: According to the conceptual framework defined by the FASB and IASB, relevance and faithful representation, as fundamental qualitative characteristics, are required for the provision of the usefulness of accounting information, and should be taken into consideration by scholars and standard setters in the accounting area.

Research limitation/Implication: This paper does not have a direct impact on practice. But, if the standard setters and researchers apply the concepts have been defined by this study in their accounting standards and their research,

*Corresponding Author: Nasrin Azar, is a PhD Scholar in the Department of Accounting, Faculty of Business and Accountancy, University of Malaya, 50603, Kuala Lumpur, Malaysia. Email: nasrinazar86@gmail.com

Zarina Zakaria, PhD is a Senior Lecturer in the Department of Accounting, Faculty of Business and Accountancy, University of Malaya, 50603, Kuala Lumpur, Malaysia. Email: zarinaz@um.edu.my Noor Adwa Sulaiman, PhD is a Senior Lecturer in the Department of Accounting, Faculty of Business and Accountancy, University of Malaya, 50603, Kuala Lumpur, Malaysia. Email: adwa@um.edu.my 
respectively, the results of those standards or research can be finally useful for the practice, especially for the investors.

Keywords: Accounting Information, FASB/IASB Conceptual Framework, Value-Relevance, Relevance, Faithful Representation

Type of manuscripts: Literature review

JEL Classification: M480

\section{Introduction}

Accounting is described as an information system that is utilised by entities to make different economic decisions (Bello, 2009). Many investors and stakeholders make their decisions based on the accounting information about the firm performance, which is provided by the financial reporting in annual reports.

Providing information that is useful for various investors in decisionmaking is the primary objective of financial statements (Dimitropoulos \& Asteriou, 2010). Van Beest, Braam, and Boelens (2009) explain that the provision of high-quality financial information about economic units and the usefulness of economic decision-making are the primary aims of financial reporting. Indeed, nobody can deny the significance of financial reporting. In other words, financial reporting quality is described as the accounting information usefulness to the users of that information (mostly named as investors and creditors). The Conceptual Framework of Financial Accounting Standard Board (FASB) (SFAC No. 2) is the initial example of this description in 1980 (Jonas \& Blanchet, 2000). Providing high-quality financial reporting information that aids investors and other stakeholders to make good decisions in investment, credit, and similar resource allocation is important and enhances the efficiency of the overall market (Norwani, Mohamad, \& Chek, 2011) as the quality of financial reporting can efficiently enhance the allocation of resources in capital markets. Moreover, the quality of financial information can help investors, analysts, owners, and regulators to make decisions about the valuation of public firms (Mashayekhi \& Abadi, 2011). The quality of financial reporting also influences the investor's point of view about future firm performance (Norwani et al., 2011). For these reasons, financial statements are expected to have a high level of quality with respect to the information they contain.

Although both the Financial Accounting Standards Board (FASB) and the International Accounting Standards Board (IASB) focus on the significance of high-quality financial reports, as established by the previous studies, the operationalisation and measurement of 'quality' are still key problems. In this regard, many scholars have measured the financial reporting quality indirectly by focusing on the specific 
characteristics of accounting information that are assumed to influence the quality of financial reporting, such as earnings management, financial restatement, and financial fraud (Cohen, Krishnamoorthy, \& Wright, 2004; Nichols \& Wahlen, 2004; Schipper \& Vincent, 2003). Moreover, Barth, Beaver, and Landsman (2001a), and Nicholas and Wahlen (2004) employ value relevance models to measure the quality of financial reporting information based on certain qualitative characteristics (QCs). These authors conceptualise the relevance attributes as defined by the FASB conceptual framework in their study. However, they only focus on the relationship between accounting numbers and stock-market reactions (share price and stock return) and not the fundamental QCs of accounting information; namely, relevance and faithful representation; as prescribed by the FASB/IASB Conceptual Framework (2010). Therefore, these ways have insufficiently addressed the comprehensive measurement of the quality of financial reporting, including the fundamental QCs as defined by the FASB/IASB (2010). As such, the FASB and the IASB (2010) jointly desire to make an appropriate measurement method to evaluate the financial reporting quality, including all aspects of decision usefulness that have not been thoroughly studied.

The primary objective of this paper is to contribute and highlight the measurement of the quality of financial reporting based on the FASB/IASB conceptual framework. For this reason, this paper defines the financial reporting quality in terms of the fundamental QCs of accounting information (relevance and faithful representation). Additionally, more scholars are interested in utilising the value relevance model as a reference to the FASB/IASB Conceptual Framework, without a proper understanding of the model, and there seems to be confusion regarding differentiating between relevance and value-relevance. In addressing this, the significance of this study is to appropriately identify the distinction between the measurement of accounting information (especially earnings) by QCs (especially relevance), as defined by the FASB/IASB (2010) and value-relevance models.

This paper is organised into four sections. The following section discusses the QCs of accounting information based on the FASB/IASB Conceptual Framework. Section three describes how earnings quality is defined by the FASB/IASB Conceptual Framework. Section four provides the definition of value-relevance models, and section five differentiates the concept of relevance and value-relevance models. Finally, in the last section, this paper presents how differentiating these two concepts will enable researchers to develop a better model for studying the quality of accounting information. 


\section{Qualitative Characteristics of Accounting Information based on the FASB/IASB Conceptual Framework (2010)}

Participants in the capital markets use financial information as a basis for their investment decision-making. Such information helps owners, creditors, firm partners, and regulators to monitor the managers' performance, estimate the past performance of a company, and predict future earnings (Bushman \& Smith, 2001, 2003).

Maines and Wahlen (2006), together with Belkaoui (2002), state that the financial reports should present accounting information that has degrees of quality, such as relevance, verifiability, understandability, neutrality, timeliness, comparability, and completeness. According to Benston (2007), the decision-making by the users of accounting information, such as investors, management, government, employees, creditors, and analysts, could be informed and qualitative if the financial reporting system discloses accounting information with high quality. According to Ghofar and Saraswati (2008), most of the time, investors are highly dependent on the quality of accounting information (Van Beest et al., 2009). Moreover, Nobes and Stadler (2014) state that managers refer to QCs when they make accounting decisions. Therefore, the study of accounting information quality has become an important topic for both accounting theoreticians and those in practice (Tzung-Yuan, 2011).

Some desirable QCs of financial information that have been introduced in some studies are transparency (Frost, Gordon, \& Hayes, 2006), conservatism (Ball, Kothari, \& Robin, 2000; LaFond \& Watts, 2008), consistency (Obaidat, 2007), credibility (Dey, 2006; Khurana \& Raman, 2004), and disclosure (Botosan \& Plumlee, 2002). However, these attributes are the different concepts used to describe the quality of accounting information and do not define the primary QCs (relevance and faithful representation) or the enhanced characteristics of accounting information as defined by FASB/IASB in 2010 (see Figure 1).

In September 2010, the FASB/IASB issued Concepts Statement No. 8. of the Conceptual Framework for Financial Reporting instead of SFACs No. 1 and No. 2, about 30 years after their adoption. In its Concepts Statement, the FASB describes: "The quality must be defined in terms of the overall objective of financial reporting, i.e., to provide users with information useful for making an investment, credit, and similar decisions." In the new framework groups, relevance and faithful representation are defined as two fundamental QCs of useful information. This means it must be relevant and faithfully represent what it purports to represent if financial information is to be useful. The usefulness of accounting information is also enhanced if it has comparability, 
verifiability, timeliness, and understandability. It can be concluded that while accounting information has both fundamental QCs, such as relevance and representation of faithfulness, the aforementioned enhancing characteristics improve the usefulness of accounting information (FASB, 2010).

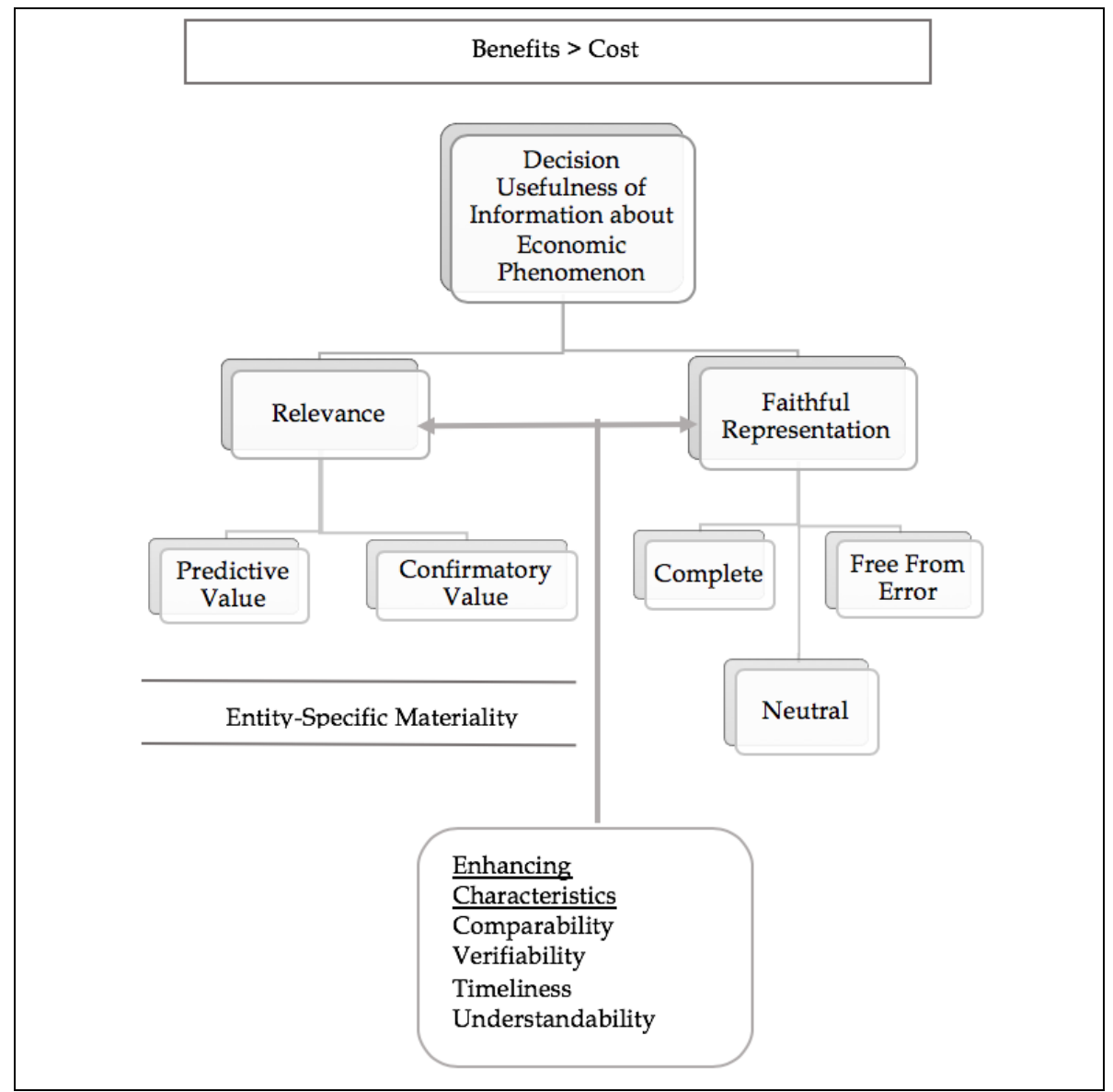

Figure 1. Financial Accounting Standards Board (FASB), Statement of Financial Accounting Concepts (SFAC) No. 8 September 2010.

Regarding enhanced QCs, some respondents to the Exposure Draft of the FASB statement have argued that all of the QCs should be taken into consideration equally and that the differentiation between the fundamental and enhancing QCs was considered random. Others said that, based on the circumstances, there are some differences among the most important QCs; therefore, the distinction among the QCs was not suitable. However, the FASB does not accept that the distinction is by 
chance. For financial information to be useful it must have the two fundamental QCs of relevance and faithful representation, and, although having greater comparability, verifiability, timeliness, and understandability might not be enough to make accounting information useful, financial information that has relevance and faithful representation may still have usefulness even without any of the enhancing QCs (FASB, 2010).

Although the FASB conceptual framework in SFAC No. 2 (1980) suggests that the degree of reliability ${ }^{\dagger}$ and relevance can vary, it does not specify any particular mix between the relevance and reliability required for the quality of information or any minimum threshold of each dimension. This means that one cannot ignore one dimension completely for the other. Barua (2006) states that little research shows which attributes of quality are more appropriate to have a better quality of accounting information.

The FASB (2010) states: "Information must be both relevant and faithfully represented if it is to be useful. Neither a faithful representation of an irrelevant phenomenon nor an unfaithful representation of a relevant phenomenon, helps users make decisions with more confidence. This results in the more efficient functioning of capital markets and a lower cost of capital for the economy as a whole. An individual investor, lender, and another creditor also receive benefits by making more informed decisions."

To be useful, information must have relevance to meet the needs of users in decision-making. Information is relevant when it affects investment decision making by aiding users to predict the future value and trends of the economic entities (Predictive Value) or to confirm or rectify any past predictions the users have made (Confirmatory Value). Moreover, the same accounting information that helps users to confirm their past predictions may be beneficial to prepare future predictions. Besides relevance, financial information needs to be presented faithfully. To be useful, financial information must not only represent relevant phenomena, but it must also faithfully represent the phenomena that it purports to represent. To be a perfectly faithful representation, a depiction would have three characteristics. It would be complete, neutral and free

tThe revised document of 2010 has two 'fundamental' qualitative characteristics: relevance (including materiality) and faithful representation. Reliability, which was discussed by the FASB conceptual framework in SFAC No. 2, 1980 was replaced by Faithfull representation in 2010). Reliability is not specifically mentioned, although the IASB has explained that it is part of 'faithful representation' (IASB 2010, paragraph BC3.24). 
from error. Of course, perfection is seldom, if ever, achievable (FASB's Conceptual Framework, 2010).

At the core of the qualitative characteristics, relevance and faithful representation (formerly, reliability) are deemed to be the two fundamental characteristics of useful accounting information. Cho, Kim, and Lim (2010) have shown that there are two mutually conflicting definitions of relevance stipulated by the original FASB Concepts Statement No. 2 of May 1980 and the IASB/FASB Exposure Draft of May 2008. They have analysed the nature of the two definitions and suggested that, based on how the concept of relevance can be used with the notion of trade-offs between relevance and faithful representation (reliability), only one definition should be retained.

In the first definition, relevance is described as the pertinence of accounting information to decisions. It typically appears in a phrase, such as, "accounting information about an economic phenomenon is capable of making a difference in the decisions made by users when it has relevance. That is, it has predictive value, confirmatory value or both." According to this explanation, accounting information is an approximation, or depiction of the determined economic phenomenon that is mostly unsuccessful in indicating the economic phenomenon perfectly. Interestingly, the conceptual frameworks of other countries mostly present this definition as the only one. In addition, this definition of relevance is often the only definition introduced by most popular US financial accounting textbooks.

However, in terms of the second description, which is found in the FASB concepts Statement No. 2 (1980) and FASB exposure draft (2008), relevance refers to the appropriateness and importance of the economic phenomenon that is selected for the decision-making by the users of the accounting information. This definition is also stated by Sloan (1999). In this regard, an economic phenomenon is usually defined as "what it purports to represent." As a matter of fact, this is the target for accounting information to represent, as selected by the standard setters. This means that standard setters have basically a dual duty of selection. They must select economic phenomena at first (based on relevance to decisionmaking) and then the principles of representation (based on the representational faithfulness of the accounting information) that, jointly, provide the decision-usefulness of accounting information. Hence, it can be stated that relevance and faithful representation are the properties of accounting information when an economic phenomenon is first selected (Cho et al., 2010). Consequently, Cho et al. (2010) believe that the true meaning of relevance is the relationship between accounting information, a particular representation of the economic phenomenon, and the 
decisions made by the users rather than the association between the economic phenomenon and the decisions. Figure 2, which has been used by Cho et al. (2010), shows the association among accounting information, economic phenomenon, and decisions with respect to certain concepts that include relevance, faithful representation, and the usefulness of decisions.

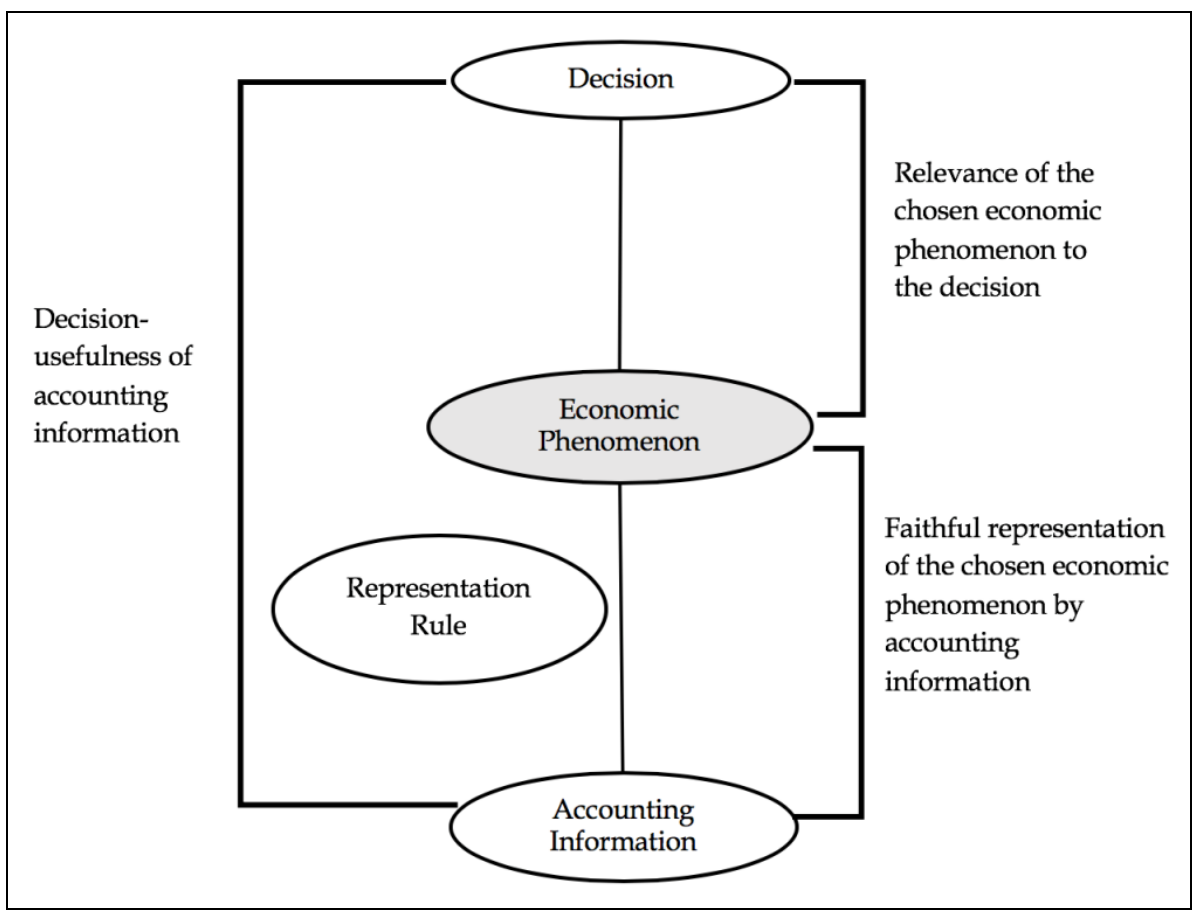

Figure 2. The association among accounting information, economic phenomenon, and decisions based on the definitions of the relevance, faithful representation, and the usefulness of decisions (Cho et al., 2010).

Accordingly, one can conclude that the second definition of relevance can be reasonable and also seems to be adopted by the FASB due to the following statements: First, it is consistent with the opinion that both relevance and representational faithfulness are necessary for the decisionusefulness, whereas regarding the first definition relevance cannot be distinguishable from the description of decision usefulness. Second, although the conceptual framework mentions that for information to be useful, it must be relevant and representationally faithful, trade-offs between these two have not been clearly described in the first definition. Because, in the first definition, relevance cannot be distinct from decisionusefulness, and, hence, representational faithfulness is required. Therefore, it could be claimed that trade-offs between relevance and 
faithful representation can be understood via the second definition (Cho et al., 2010).

\section{Earnings and Earnings Quality}

Earnings have been established as a summary measure of firm performance. That is why scholars consider them as very important accounting information. As earnings are deemed to be significant information in financial statements, consequently, earnings quality is also considered to be significant information for the financial information users, such as practitioners, standard setters, regulators, and accounting scholars (Biddle, Hilary, \& Verdi, 2009; Francis, LaFond, Olsson, \& Schipper, 2004; Schipper \& Vincent, 2003). Therefore, earnings are considered as the particular accounting information in this study.

In recent decades, regulators, managers, investors, practitioners, and academic researchers have given much interest to earnings quality. The emphasis on earnings quality is also due to the increasing corporate and accounting scandals in the business world, such as Enron, WorldCom, Xerox, Parmalat, Vivendi, and Credit Lyonnais (Ayadi \& Boujelbène, 2015).

Accordingly, many researchers have documented that poor quality information, particularly earnings, is the reason for the increasing information asymmetry and the rising cost of equity (Bhattacharya, Desai, \& Venkataraman, 2013; Francis et al., 2004; Lara, Osma, \& Penalva, 2011; $\mathrm{Ng}, 2011)$. The quest to explore how accounting information (particularly earnings) is useful for stakeholders in decision-making has become the major motivation for accounting studies, and has attracted considerable research (Bhattacharya et al., 2013; Dechow \& Schrand, 2004; Schipper \& Vincent, 2003). Although many types of research have been conducted to define earnings attributes and measure earnings informativeness or earnings quality using various tools, so far, financial analysts have not been able to identify a suitable measure of earnings quality regardless of their perspective (Jenkins, Kane, \& Velury, 2006). Hence, Harris, Huh, and Fairfield (2000) believe that the definition of earnings quality is not a proven subject that can be comprehended easily, but a concept that, to a certain extent, depends on its association with the realisation, understanding, and the approach.

In accounting research, many studies utilise different attributes of earnings quality constructs including the predictive value of earnings (Cohen et al., 2004; Mikhail, Walther, \& Willis, 2003), earnings persistence (Penman \& Zhang, 2002; Skinner, 2004), association between accruals and cash flows (Dechow \& Dichev, 2002), discretionary accruals (Aboody, 
Hughes, \& Liu, 2005; Lee \& Yue, 2004), and total and operating accruals (Richardson, Sloan, Soliman, \& Tuna, 2005). Moreover, seven attributes of earnings - accrual quality, persistence, predictability, smoothness, value relevance, timeliness, and conservatism - have been defined by Francis et al. (2004). In their research, the first four attributes are normally measured by using accounting information only. That is why they characterise them as accounting-based. In addition, the proxies for the last three attributes are basically defined by the relations between the accounting data and market data. Hence, those attributes are described as market-based (J. Francis et al., 2004) (see Figure 3).

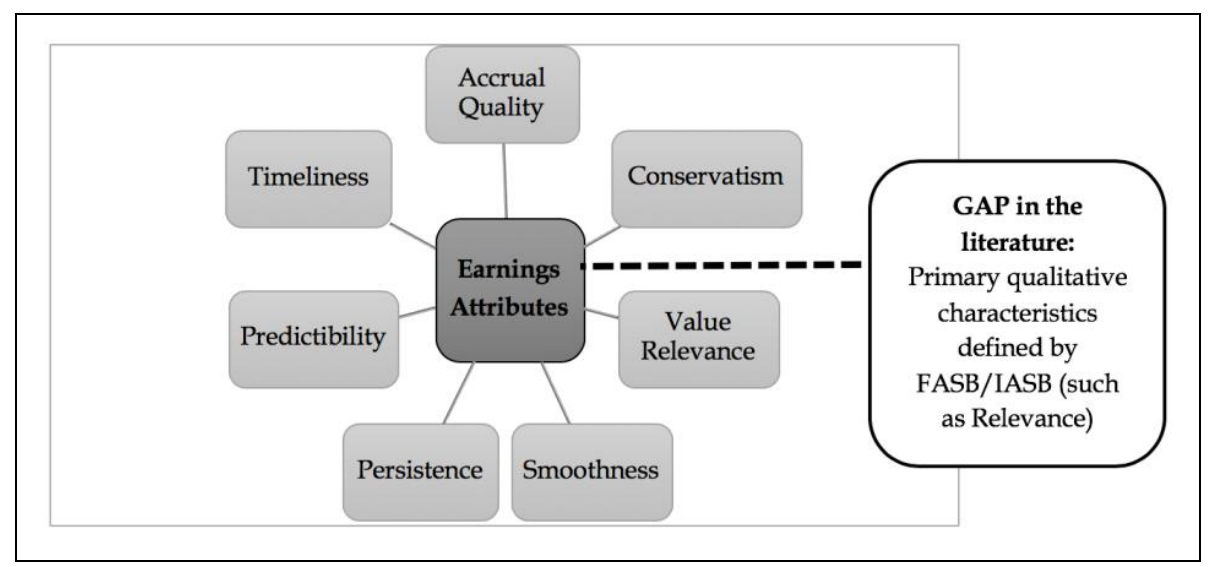

Figure 3. Some attributes to measure the quality of earnings

However, previous studies have utilised either one dimension or a single component of one dimension of earnings quality (as specified in the FASB's conceptual framework) to measure the constructs of earnings quality. Thus, by concentrating on one dimension or a single component of one dimension of earnings quality, they do not mention all the information about the quality of earnings in their empirical studies. For this reason, in 2006, in his dissertation, Barua developed a measure of earnings quality with respect to the fundamental QCs defined by FASB in the statement of financial accounting concepts (SFAC) No. 2 in 1980, as he believed that previous studies, especially Francis et al. (2004), do not form a comprehensive explanation of the earnings quality.

\section{Value-relevance Models}

One of the most important problems in finance and accounting is how well the information content of accounting numbers represents the stock prices/returns. Ball and Brown (1968) conducted the first study in this 
regard. They conclude that unexpected earnings have a significant association with the abnormal stock returns. Subsequently, many researchers have conducted similar studies in various markets (Brimble \& Hodgson, 2007; Collins, Maydew, \& Weiss, 1997; Frankel \& Lee, 1999; Pathirawasam, 2010; Rossi, 2017).

The main objective of financial statements is to disclose the company's performance. According to Pathirawasam (2013), if there is no association between accounting numbers in the financial statements and firm value, the value relevance cannot be described for the accounting numbers in the financial statements. Hence, he also believes that nobody can rely on those accounting numbers. Finally, he concludes that, to directly examine the validity and reliability of financial statements published by companies, a value relevance study should be taken into consideration.

Among the attributes addressed by Francis et al. (2004), although value relevance seems to be close to the concept of relevance, there are some contradictions and differences that will be clarified in the following, thereby leading to the problem this study intends to highlight.

If accounting information has a predicted relationship with the market values of the equity, i.e., share prices and stock returns, it is defined as value-relevant information. Value-relevance studies are developed to evaluate whether particular accounting numbers represent information that is utilised by the investors to value the equity of the firms (Barth et al., 2001a; Barth, 2015).

The subject of value-relevance as an important topic is worth studying since financial statements are significant for firms to communicate to shareholders, and, what's more, to the public, (Ogeh Fiador, 2013). The usage of accounting numbers to advance the analysts' earnings forecasts is one of the applications of the value-relevance studies. On the one hand, to predict earnings accurately, most of the time, analysts need to find new procedures. On the other hand, shareholders might be interested in those methods in which they are able to address the bias in forecasting by analysts and thereby enhance the precision of existing forecasts. Generally, where fundamental analysis can be defined as identifying ways to use accounting information to produce forecasts of earnings with high quality, the rise of "fundamental analysis" research in accounting leads to the application of the value-relevance studies (Nissim \& Penman, 2001).

Some researchers define the value-relevance of accounting information as the ability of financial information to represent data that affect the measurement of the stock market, i.e., stock returns and share price (Francis \& Schipper, 1999; Ogeh Fiador, 2013; Shan, 2015). The theoretical framework of equity valuation models is the main reason for 
the value relevance studies (Sharma, Kumar, \& Singh, 2012). Different valuation models, such as the Price Regression Model (PRM) and the Return Regression Model (RRM), are used by the value relevance studies to construct the value-relevance tests (Onali, Ginesti, \& Vasilakis, 2017).

Value relevance is generally measured as the ability of earnings to explain variation in returns (Stock Return Model) or share price (Share Price Model), where greater explanatory power is viewed as desirable (see Figure 4).

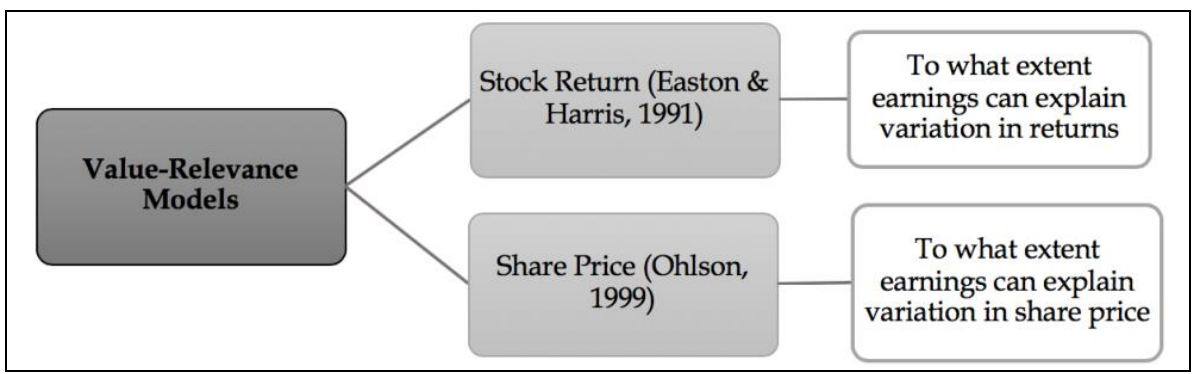

Figure 4. Different types of Value-Relevance Models to measure earnings quality

According to Francis et al. (2004), the measure of value relevance of earnings is based on the regression of the annual stock returns on the levels of, and changes in annual earnings, which are measured by the adjusted-

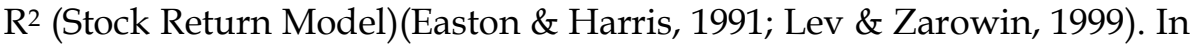
this way, Klai and Omri (2011), Niu (2006), and Vafeas (2000) measured earnings quality by this method during their studies. However, there are some weaknesses in this association. First, the timeliness of accounting earnings in those studies is not considered to be the earnings quality construct. Second, mismatching of revenues and expenses addresses a concern in the model's effectiveness. Third, a misrepresentation of the true return-earnings relationship occurs by the errors in estimating (Pathirawasam, 2013).

Thus, compared to the returns model, the price model (Ohlson Model) is more appropriate as it normally uses the equity market value to evaluate to what extent the information used by shareholders is reflected by the specific accounting numbers. Ohlson (1995) states that firm value can be mentioned as a linear function of book value, earnings, and other value relevant information. Accordingly, many studies usually accept value relevance methodology to examine the quality of accounting principles by using share price models. Amir, Harris, and Venuti (1993)seem to be the first ones to use the term "value relevance" to define this relationship. Barth et al. (2001a) also define value relevance, which is similar to the one 
above. Alkdai and Hanefah (2012), and Ogeh Fiador (2013) also use this association to explore the influence of corporate governance on the value relevance of accounting information. Additionally, some issues have been introduced in terms of price model. First, stock price formation is a complicated procedure because the governance usefulness of information is limited due to the potential information aggregated in price (Paul, 1992). As a result, substituting share price as an information source for poor accounting amount seems to have a main error (Hribar \& Collins, 2002). Second, Lipe (1990) states that, compared to the other useful information, the relative ability of earnings to predict future earnings influences the stock return and share price reaction to the earnings. To sum up, the above-mentioned concepts concern how the accounting literature has defined and applied the value-relevance of earnings.

\section{Critical Evaluation of the Differences between the FSAB/IASB Conceptual Framework and Value-relevance Models}

Turning to the definition of certain concepts regarding the QCs of accounting information in Section 2, and also with respect to the explanation of the value relevance models in the preceding section, this section identifies several differences between these two concepts as provided in the literature. Some of the propositions created by studies in value-relevance are not compatible with the FASB statements. This is the main objective and contribution of this study, which is discussed as follows.

First, according to the conceptual framework, the QCs of earnings are defined by two attributes - the relevance and reliability - that provide useful information for the users to make the decisions (FASB 2010), while, according to the aforementioned explanations, value relevance often refers to the earnings' ability in explaining the variation of the returns or stock price, where the desirable view is the higher explanatory power (Beisland, 2009). Second, in the same vein, Barth et al. (2001a), and Francis et al.(2004) claim that value relevance exhibits one method to operationalise two primary characteristics - relevance and reliability - as stated by the FASB. They claim that the relationship between accounting numbers and stockmarket reflections - named the value relevance approach - measures the quality of accounting information (Barth et al., 2001a; Cho et al., 1997; Nichols \& Wahlen, 2004).

It is claimed that the firm market value is presented by the stock price, whereas firm value is presented by the accounting numbers based on accounting rules and principles. When one correlates these two above 
explanations, i.e., the variation in accounting information compatible to the variation in the market value of the firm, it is presumed that relevant and reliable information can be provided by the earnings information (Nichols \& Wahlen, 2004; Barth, 2015). They also mention that although the value relevance model examines the relevance and reliability jointly (which is focused on by FASB). They also mentioned that value relevance model examines the relevance and reliability jointly (which is focused by FASB). Thus, to some extent, achieving the good results in the value relevance model indicates the accounting number has relevance and reliability. However, when the model shows the case in which there is the lack of value relevance, allocating the cause of the lack of the relevance or the reliability is difficult. This means that this model does not differentiate between relevance and reliability. In addition, the efficiency of the stock market may not be comprehensive. As a result, the market value of the firm may not be accurately represented by the stock prices (Nichols \& Wahlen, 2004; Van Beest et al., 2009).

Consequently, according to Kim and Kross (2005), and Collins et al. (1997), the price model (association between price and earnings in value relevance research) defines earnings usefulness as a whole rather than relevant or reliability as components of usefulness. That is why the narrow body of literature illuminates how value relevance measures the decision usefulness directly. Long before the description of the QCs of accounting information by SFAC No. 2, Ball and Brown (1968) proposed the measurement of the earnings information usefulness by the relationship between stock returns and earnings. Moreover, Lev and Zarowin (1999) argue that the accounting information usefulness is represented by the returns-earnings correlation. They also explain that the usefulness is decreased when the returns-earnings correlation fails because the results of investors' actions are reflected in such a correlation (Collins et al., 1997; Francis \& Schipper, 1999; Harris, Lang, \& Mőller, 1994; Lev \& Zarowin, 1999).

Third, Barth, Cram, and Nelson (2001b) state that the studies on the value relevance have been developed to evaluate how well the information that is utilised by shareholders in the firm's equity valuation is reflected by the specific accounting numbers. Moreover, they claim that the concept of usefulness has not been adequately defined in accounting research and that value relevance studies have not been developed to evaluate the usefulness of accounting information. However, this statement is inconsistent with the FASB conceptual framework, which claims that the quality of financial reporting is a determination of how the financial information is relatively useful for the users. In other words, the 
objective of financial reporting is providing the users with useful information and promoting their ability to make an investment, credit, or similar decisions.

Fourth, one of the differences between the value-relevance models and the FASB statement concerns the users and uses of financial reporting, which have been explained by Holthausen \& Watts (2001). The valuerelevance studies propose that the dominant users of financial reporting are the equity investors and that the dominant use of financial reporting is a valuation of equity, while, in addition to equity users, the FASB statements also highlight the non-equity investors and their uses of financial reporting in the regulating of accounting rules and standards. Fifth, the value-relevance studies describe an alternative proposition which is not applied by the FASB statements. This preposition is that the equity investors' use of accounting information in the valuation of the firm's equity is represented by the stock prices sufficiently. However, the FASB obviously reject that the aim of financial reporting is the direct valuation of the firm's equity. In this case, the FASB states: "information (provided by financial reports) may help those who desire to estimate the value of a business enterprise, but financial accounting is not designed to measure directly the value of an enterprise" (SFAC No. 1, paragraph 41.) (Holthausen \& Watts, 2001).

\section{Conclusion}

One of the most important consequences of the variations of the objectives and fundamental QCs for financial reporting is assumed to improve confidence in the financial reporting and to reduce the possibility of the misusing of financial reporting information, and, therefore, secondarily, make the system of financial markets strong. Nobody has denied that the fundamental QCs are crucial to making a decision by the users. Users of accounting information, as the basis for their decisions, need relevant and reliable information, which should be improved through the help of the assurance services.

Regarding that, the variations focused on by the FASB/IASB in 2010, particularly in the area of financial reporting quality, will affect the quality of the content of information for shareholders and other stakeholders, thereby enabling them to make their economic decisions effectively.

According to the definition of fundamental QCs, it can be concluded that there are some mixed results in some of the research conducted before. This includes Barth et al. (2001a), who claim that the valuerelevance of the accounting variable, which is measured by the relationship of accounting information with share prices or returns, is both 
relevant and not totally unreliable. Consequently, value-relevance studies that solely follow this definition of primary QCs rule out a total absence of being relevant and faithfully represented.

While there are many value-relevance studies, their assistance to the users who need qualified information (relevant and faithfully represented) seems modest. There are a variety of differences between the valuerelevance literature and the primary QCs of accounting information based on FASB/IASB. There is an assumption that accounting prepares some information for the investors to enable them in terms of the valuation of the firm's equity. This assumption is the main motivation for researchers to study the value-relevance. Even studies that try to tease out the two primary QCs (relevance and reliability) described by the FASB, to some extent, depend on those characteristics that are represented in the market values of equity. Although exploration by the value-relevance literature helps us to understand how accounting information plays a role in providing investors inputs to value a firm's equity, those examinations and studies have missed the other effects of accounting information in terms of investment decision-making. To an extent, decision-making is based on accounting information formed by other effects that are not completely related to the role of equity valuation. Thus, in this paper, it is highlighted that the attributes defined by the FASB/IASB conceptual framework are substantive and should be taken into consideration by the users of accounting information to make the best decision in the capital markets.

Consequently, it seems that the value-relevance studies ignore the fundamental QCs of accounting information as defined by the FASB/IASB. For this reason, the probable distinction between the attributes, as defined by the FASB (relevance and reliability), and the attributes represented in stock market associations (value-relevance models), which has not been studied, need to be taken into consideration by future studies. This paper is a review paper, which is useful for academicians and researchers. This paper is not a methodological paper whose results would have a direct impact on practice. However, if the standard setters and researchers apply the concepts have been defined by this study in their accounting standards and their research, respectively, the results of those standards or research can be finally useful for the practice.

\section{References}

Aboody, D., Hughes, J., \& Liu, J. (2005). Earnings quality, insider trading, and cost of capital. Journal of Accounting Research, 43(5), 651-673. 
Alkdai, H. K. H., \& Hanefah, M. M. (2012). Board of directors' characteristics and value relevance of accounting information in Malaysian shariah-compliant companies: a panel data analysis. Economics and Finance Review, 2(6), 31-44.

Amir, E., Harris, T. S., \& Venuti, E. K. (1993). A comparison of the value-relevance of US versus non-US GAAP accounting measures using form 20-F reconciliations. Journal of Accounting Research, 31, 230-264.

Ayadi, W. M., \& Boujelbène, Y. (2015). Internal governance mechanisms and value relevance of accounting earnings: an empirical study in the French context. International Journal of Managerial and Financial Accounting, 7(1), 3-25.

Ball, R., \& Brown, P. (1968). An empirical evaluation of accounting income numbers. Journal of Accounting Research, 6(2), 159-178.

Ball, R., Kothari, S., \& Robin, A. (2000). The effect of international institutional factors on properties of accounting earnings. Journal of Accounting and Economics, 29(1), 1-51.

Barth, M. E. (2015). Financial accounting research, practice, and financial accountability. Abacus-a Journal of Accounting Finance and Business Studies, 51(4), 499-510.

Barth, M. E., Beaver, W. H., \& Landsman, W. R. (2001). The relevance of the value relevance literature for financial accounting standard setting: another view. Journal of Accounting and Economics, 31(1), 77-104.

Barth, M. E., Cram, D. P., \& Nelson, K. K. (2001). Accruals and the prediction of future cash flows. The Accounting Review, 76(1), 27-58.

Barua, A. (2006). Using the FASB's Qualitative Characteristics in Earnings Quality Measures*. Available at SSRN 815784.

Beisland, L. A. (2009). A review of the value relevance literature. The Open Business Journal, 2(1), 7-27.

Belkaoui, A. R. (2002). Accounting theory (Vol. 4th edition). United Kingdom: T. J. International.

Bello, A. (2009). Financial information quality and inflation accounting disclosure in Nigerian cement industry. Ph.D. Dissertation submitted to the Postgraduate School of Ahmadu Bello University, Zaria - Nigeria.

Benston, G. J. (2007). Contemporary issues in financial reporting: a user-oriented approach. February, 23-32.

Bhattacharya, N., Desai, H., \& Venkataraman, K. (2013). Does Earnings Quality Affect Information Asymmetry? Evidence from Trading Costs*. Contemporary Accounting Research, 30(2), 482-516.

Biddle, G. C., Hilary, G., \& Verdi, R. S. (2009). How does financial reporting quality relate to investment efficiency? Journal of Accounting and Economics, 48(2-3), 112-131.

Board, F. A. S. (1980). Statement of financial accounting concepts No. 2: qualitative characteristics of accounting information. Stamfort, CT: FASB.

Board, F. A. S. (2010). Conceptual Framework for Financial Reporting. Statement of Financial Accounting Concepts No. 8: FASB Norwalk, CT.

Botosan, C. A., \& Plumlee, M. A. (2002). A re-examination of disclosure level and the expected cost of equity capital. Journal of Accounting Research, 40(1), 21-40. 
Brimble, M., \& Hodgson, A. (2007). On the intertemporal value relevance of conventional financial accounting in Australia. Accounting and Finance, 47(4), 599-622.

Bushman, R. M., \& Smith, A. J. (2001). Financial accounting information and corporate governance. Journal of Accounting and Economics, 32(1), 237-333.

Bushman, R. M., \& Smith, A. J. (2003). Transparency, financial accounting information, and corporate governance. Financial Accounting Information, and Corporate Governance. Economic Policy Review, 9(1), 65-87.

Cho, M., Kim, O., \& Lim, S. C. (2010). Two conflicting definitions of relevance in the FASB Conceptual Framework. Journal of Accounting and Public Policy, 29(6), 604-611.

Cohen, J. R., Krishnamoorthy, G., \& Wright, A. (2004). The corporate governance mosaic and financial reporting quality. Journal of Accounting Literature, 34, 87152.

Collins, D. W., Maydew, E. L., \& Weiss, I. S. (1997). Changes in the value-relevance of earnings and book values over the past forty years. Journal of Accounting and Economics, 24(1), 39-67.

Dechow, P. M., \& Dichev, I. D. (2002). The quality of accruals and earnings: The role of accrual estimation errors. The Accounting Review, 77(s-1), 35-59.

Dechow, P. M., \& Schrand, C. M. (2004). Earnings quality.

Dey, A. (2006). Corporate Governance and Financial Reporting Credibility. Northwestern University.

Dimitropoulos, P. E., \& Asteriou, D. (2010). The effect of board composition on the informativeness and quality of annual earnings: Empirical evidence from Greece. Research in International Business and Finance, 24(2), 190-205.

Easton, P. D., \& Harris, T. S. (1991). Earnings as an explanatory variable for returns. Journal of Accounting Research, 29(1), 19-36.

Francis, \& Schipper. (1999). Have financial statements lost their relevance? Journal of Accounting Research, 37(2) 319-352.

Francis, J., LaFond, R., Olsson, P. M., \& Schipper, K. (2004). Costs of equity and earnings attributes. The Accounting Review, 79(4), 967-1010.

Frankel, R., \& Lee, C. M. (1999). Accounting diversity and international valuation. Ann Arbor, 1001, 48109-41234.

Frost, C. A., Gordon, E. A., \& Hayes, A. F. (2006). Stock exchange disclosure and market development: An analysis of 50 international exchanges. Journal of Accounting Research, 44(3), 437-483.

Ghofar, A., \& Saraswati, E. (2008). Problems in financial reporting: the analysis of quality of disclosure and the measurement system of the traditional accounting: Retrieved on 28/11/2010 from http:/ / www.indonesiauniversity.edu.in/

Harris, Lang, M., \& Móller, H. P. (1994). The value relevance of German accounting measures: An empirical analysis. Journal of Accounting Research, 32(2), 187-209.

Harris, T., Huh, E., \& Fairfield, P. (2000). Gauging profitability on the road to valuation. Strategy report, global valuation and accounting, Morgan Stanley Dean Witter. 
Holthausen, R. W., \& Watts, R. L. (2001). The relevance of the value-relevance literature for financial accounting standard setting. Journal of Accounting and Economics, 31(2001), 2003-2075.

Hribar, P., \& Collins, D. W. (2002). Errors in estimating accruals: implication for empirical research. Journal of Accounting Research, 40(3), 727-759.

IASB, F. (2008). EXPOSURE DRAFT: Conceptual Framework for Financial Reporting: The Objective of Financial Re-porting and Qualitative Characteristics and Constraints of Decision Useful Financial Reporting Information.

Jenkins, D. S., Kane, G. D., \& Velury, U. (2006). Earnings quality decline and the effect of industry specialist auditors: An analysis of the late 1990s. Journal of Accounting and Public Policy, 25(1), 71-90.

Jonas, G. J., \& Blanchet, J. (2000). Assessing quality of financial reporting. Accounting Horizons, 14(3), 353-363.

Khurana, I. K., \& Raman, K. (2004). Litigation risk and the financial reporting credibility of Big 4 versus non-Big 4 audits: Evidence from Anglo-American countries. The Accounting Review, 79(2), 473-495.

Kim, M., \& Kross, W. (2005). The ability of earnings to predict future operating cash flows has been increasing - not decreasing. Journal of Accounting Research, 43(5), 753-780.

Klai, N., \& Omri, A. (2011). Corporate governance and financial reporting quality: The case of Tunisian firms. International Business Research, 4(1), 158-166.

LaFond, R., \& Watts, R. L. (2008). The information role of conservatism. The Accounting Review, 83(2), 447-478.

Lara, J. M. G., Osma, B. G., \& Penalva, F. (2011). Conditional conservatism and cost of capital. Review of Accounting Studies, 16(2), 247-271.

Lee, C., \& Yue, H. (2004). Timeliness and earnings quality. Paper presented at the American Accounting Association Annual Meeting, Orlando, FL.

Lev, B. (1989). On the usefulness of earnings and earnings research: Lessons and directions from two decades of empirical research. Journal of Accounting Research, 27, 153-192.

Lev, B., \& Zarowin, P. (1999). The Boundaries of Financial Reporting and How to Extend Them (Digest Summary). Journal of Accounting Research, 37(2), 353-385.

Lipe, R. (1990). The relation between stock returns and accounting earnings given alternative information. The Accounting Review, 65(1), 49-71.

Maines, L. A., \& Wahlen, J. M. (2006). The nature of accounting information reliability: Inferences from archival and experimental research. Accounting Horizons, 20(4), 399-425.

Mashayekhi, B., \& Abadi, M. M. (2011). The relationship between Corporate Governance and Earning Quality. Journal of Finance Accounting Research, 2(8), 18-32.

Mikhail, M. B., Walther, B. R., \& Willis, R. H. (2003). Reactions to dividend changes conditional on earnings quality. Journal of Accounting, Auditing \& Finance, 18(1), 121-152.

$\mathrm{Ng}$, J. (2011). The effect of information quality on liquidity risk. Journal of Accounting and Economics, 52(2), 126-143. 
Nichols, D. C., \& Wahlen, J. M. (2004). How do earnings numbers relate to stock returns? A review of classic accounting research with updated evidence. Accounting Horizons, 18(4), 263-286.

Nissim, D., \& Penman, S. H. (2001). Ratio analysis and equity valuation: From research to practice. Review of Accounting Studies, 6(1), 109-154.

Niu, F. F. (2006). Corporate governance and the quality of accounting earnings: a Canadian perspective. International Journal of Managerial Finance, 2(4), 302-327.

Nobes, C. W., \& Stadler, C. (2014). The qualitative characteristics of financial information, and managers' accounting decisions: evidence from IFRS policy changes.

Norwani, N. M., Mohamad, Z. Z., \& Chek, I. T. (2011). Corporate Governance Failure And Its Impact On Financial Reporting Within Chosen Companies. International Journal of Business and Social Science, 2(21), 205-213.

Obaidat, A. N. (2007). Accounting Information Qualitative Characteristics Gap: Evidence from Jordan. International Management Review, 3(2), 26-32.

Ogeh Fiador, V. (2013). Corporate governance and value relevance of financial information: evidence from the Ghana Stock Exchange. Corporate Governance, 13(2), 208-217.

Ohlson, J. A. (1995). Earnings, book values, and dividends in equity valuation. Contemporary Accounting Research, 11(2), 661-687.

Ohlson, J. A. (1999). On transitory earnings. Review of Accounting Studies, 4(3-4), 145-162.

Onali, E., Ginesti, G., \& Vasilakis, C. (2017). How should we estimate valuerelevance models? Insights from European data. The British Accounting Review, 49(5), 460-473.

Pathirawasam, C. (2010). Value relevance of accounting information: evidence from Sri Lanka. International Journal of Research in Commerce and Management, 1(8), 13-20.

Pathirawasam, C. (2013). The Value Relevance of Earnings and Book Value: The Importance of Ownership Concentration and Firm Size. Journal of Competitiveness, 5(2), 98-107.

Paul, J. M. (1992). On the efficiency of stock-based compensation. Review of Financial Studies, 5(3), 471-502.

Penman, S. H., \& Zhang, X.-J. (2002). Accounting conservatism, the quality of earnings, and stock returns. The Accounting Review, 77(2), 237-264.

Richardson, S. A., Sloan, R. G., Soliman, M. T., \& Tuna, İ. (2005). Accrual reliability, earnings persistence and stock prices. Journal of Accounting and Economics, 39(3), 437-485.

Rossi, J. A. (2017). Revisiting the Value Relevance of Accounting Information in the Italian and UK Stock Markets Value Relevance of Accounting Information in Capital Markets (pp. 102-113): IGI Global.

Schipper, K., \& Vincent, L. (2003). Earnings quality. Accounting Horizons, 17, 97110.

Shan, Y. G. (2015). Value relevance, earnings management and corporate governance in China. Emerging Markets Review, 23, 186-207. 
Sharma, A. K., Kumar, S., \& Singh, R. (2012). Value relevance of financial reporting and its impact on stock prices: evidence from India. South Asian Journal of Management, 19(2), 60-77.

Skinner, D. J. (2004). What do dividends tell us about earnings quality. Unpublished working paper. University of Michigan, Ann Arbor, Michigan.

Sloan, R. G. (1999). Evaluating the reliability of current value estimates. Journal of Accounting and Economics, 26(1), 193-200.

Tzung-Yuan, H. (2011). Do the results of information transparency reflect firms' accounting quality? African Journal of Business Management, 5(26), 10545-10549.

Vafeas, N. (2000). Board structure and the informativeness of earnings. Journal of Accounting and Public Policy, 19(2), 139-160.

Van Beest, F., Braam, G., \& Boelens, S. (2009). Quality of Financial Reporting: measuring qualitative characteristics. Nijmegen Center for Economics (NiCE). Working Paper, 09-108. 